\title{
Production regularity of 'Ponkan' mandarin trees submitted to chemical thinning
}

\section{Regularidade de produção de tangerineira 'Ponkan' submetida a raleio químico}

\author{
Maria do Céu Monteiro Cruz ${ }^{1 *}$; Rodrigo Amato Moreira²
}

\begin{abstract}
Alternate bearing is a problem that has influenced the productivity and fruits quality of 'Ponkan' mandarin trees. The aim of this research was to evaluate the effect of chemical thinning on alternate bearing and productivity of 'Ponkan' mandarin tree. Ten-year-old plants grafted on 'Rangpur' lime (Citrus limonia Osbeck) were evaluated in a commercial orchard from December 2006 to July 2008. Five Ethephon concentrations were applied: 0, 150,300, 450 and $600 \mathrm{mg} \mathrm{L}^{-1}$ in two fruit development stages ( $30 \mathrm{~mm}$ and $40 \mathrm{~mm}$ of transverse diameter). The experiment was set in a $5 \times 2$ factorial scheme, in randomized blocks with four replications. In the first year after chemical thinning with Ethephon the productivity was evaluated in plants of different treatments. In the second year the alternate bearing and the productivity were evaluated. The chemical thinning promotes yield regularity in 'Ponkan' mandarin trees, with the application of Ethephon at concentrations between $300 \mathrm{mg} \mathrm{L}^{-1}$ to $600 \mathrm{mg} \mathrm{L}^{-1}$. Plants sprayed with $600 \mathrm{mg} \mathrm{L}^{-1}$ of Ethephon produced fruit higher amounts in following year to thinning.
\end{abstract}

Key words: Citrus reticulata Blanco, alternate bearing, Ethephon

\section{Resumo}

Para a tangerineira 'Ponkan', a alternância de produção é um problema que tem influenciado a qualidade das frutas e a produtividade. A finalidade desta pesquisa foi avaliar os efeitos do raleio químico sobre a alternância de produção e produtividade da tangerineira 'Ponkan'. Foram utilizadas tangerineiras 'Ponkan' enxertadas sobre limoeiro 'Cravo' (Citrus limonia Osbeck), de um pomar comercial com dez anos de idade, no período de dezembro de 2006 a julho de 2008. As plantas foram pulverizadas com cinco concentrações de Ethephon: 0, 150, 300, 450, $600 \mathrm{mg} \mathrm{L}^{-1}$, em dois estádios de desenvolvimento das frutas: 30 e $40 \mathrm{~mm}$ de diâmetro transversal. Foi utilizado o esquema fatorial $5 \times 2$, disposto em blocos casualizados, com quatro repetições. No primeiro ano, após a aplicação do raleio químico com Ethephon, foi avaliado o rendimento da produção nas plantas dos diferentes tratamentos. No segundo ano foram determinadas a alternância de produção e a produtividade. O raleio químico promove a regularidade de produção em tangerineira 'Ponkan' com aplicação de Ethephon em concentrações entre 300 e $600 \mathrm{mg} \mathrm{L}^{-1}$. As plantas pulverizadas com a concentração de $600 \mathrm{mg} \mathrm{L}^{-1}$ produziram alta quantidade de frutos no ano subsequente ao raleio.

Palavras-chave: Citrus reticulata Blanco, alternância de produção, Ethephon

\footnotetext{
${ }^{1}$ Eng $^{\mathrm{a}} \mathrm{Agr}^{\mathrm{a}}$, Pós-D.Sc. Prof ${ }^{\mathrm{a}}$. do Dept ${ }^{\mathrm{o}}$ de Agronomia, Universidade Federal dos Vales do Jequitinhonha e Mucuri, UFVJM, Campus JK, Diamantina, MG. E-mail: mariceu@ufvjm.edu.br

${ }^{2}$ Eng $^{\mathrm{o}}$ Agr $^{\mathrm{o}}$, Doutorando do Programa de Pós-Graduação em Fitotecnia, Universidade Federal de Lavras, UFLA, Lavras, MG. E-mail: amatomoreira@yahoo.com.br

* Author for corespondence
} 


\section{Introduction}

The mandarin 'Ponkan' tree produces one of the most appreciated tangerines to in natura consumption due to the facility of removing the bark and gores, so it is cultivated in various regions of the world. However, this cultivar is the behavior of alternate bearing.

The alternate bearing, characterized by excessive production interspersed with years of low production, is a problem in 'Ponkan' mandarin culture. This is because in years of greater production, the fruits are small and have low quality, which make their marketing difficult, according to market demand for in nature fruit consumption, which prefers largesize fruits.

Techniques that can be used to alleviate this problem include fruit thinning with the application of exogenous phytoregulators. This practice has been done to reduce the fruit amount, improve quality and reduce the alternate bearing effect by changing the source-sink relationship. The enhancement of carbohydrate availability was associated with an improvement of fruit set and yield of citrus trees (GOLDSCHMIDT, 1999). The effects of carbohydrates on fruit growth are relationship by a wide body of evidence including studies on fruit thinning (IGLESIAS et al., 2003) because the fruit growth depend of assimilates supply rate from sources (GARCÍA-LUIS et al., 2002).

The thinning can increase the fruit size and crop value. Moreover, it can promote the flowering in the following year. Because the carbohydrates exhaustion for fruit in years of high production influences the flowering in subsequent year due the flowers number produced is extremely high in comparison with the number of fruits that the tree can support until ripening. However, to achieve significant increase in fruit size requires a drastic reduction in the fruits number (SCHWARZ; KOLLER; NIENOW, 1992). This results in significant reduction in total yield crop, although it can economically offset through increasing of the fruit size produced (GUARDIOLA; GARCÍALUIZ, 2000). Because chemical thinning is an alternative aimed at differentiated markets, such as table fruit market, as well as be able to reduce costs, improve quality and can add value.

In 'Montenegrina' mandarin $(C$. deliciosa Tenore), the alternate bearing was broken in a satisfactory manner using the Ethephon concentration of $200 \mathrm{mg} \mathrm{L}^{-1}+3 \%$ of urea (SOUZA et al., 1993). However, the Ethephon thinning application to promote the fruit quality improvement and alternate bearing reduction depends on the age of plants, of thinning completion time and environmental interaction conditions. Sartori et al. (2007) observed no reduction of alternate bearing in 'Montenegrina' mandarin with the $200 \mathrm{mg} \mathrm{L}^{-1}$ Ethephon concentration, as no observed effect on the thinning of fruit.

The improvement of the productive process with the application of growth regulators has been reported by other researchers (LEITE; CRUSCIOL; SILVA, 2011, CRUZ; MOREIRA; ARAUJO, 2011). However, the results are variable due to differences between the cultivars, concentrations of growth regulators used and the interaction with the conditions of the cultivation region, making himself necessary research to know its effects on physiological behavior and productive of plants.

The phytoregulators application such as Ethephon (2-chloroethylphosphonic acid), favors the increase in fruit size by increasing the metabolites availability for the remaining fruit. In addition, chemical thinning reduces the problem of alternate bearing in 'Ponkan' mandarin to avoid the plant depletion due the reduction of fruit number excessive per plant. Thus, the aim of this work was to evaluate the effect of chemical thinning on the alternate bearing and productivity of 'Ponkan' mandarin. 


\section{Material and Methods}

The research was developed in a non-irrigated commercial orchard situated in Perdões $21^{\circ} 05^{\prime} 27^{\prime \prime}$ (S) and 45 $05^{\prime} 27^{\prime \prime}(\mathrm{W})$, southern Minas Gerais State, Brazil. The region's average altitude is 900 meters and climate type is $\mathrm{Cwb}$, characterized by hot and wet summers and dry and cold winters according the Köppen classification. Data of temperature, precipitation and relative humidity were recorded from thinning completion (Figure 1).

Figure 1. Average temperature, relative humidity and rainfall during the experimental period 2007 and 2008 in Perdões, southern Minas Gerais State, Brazil.

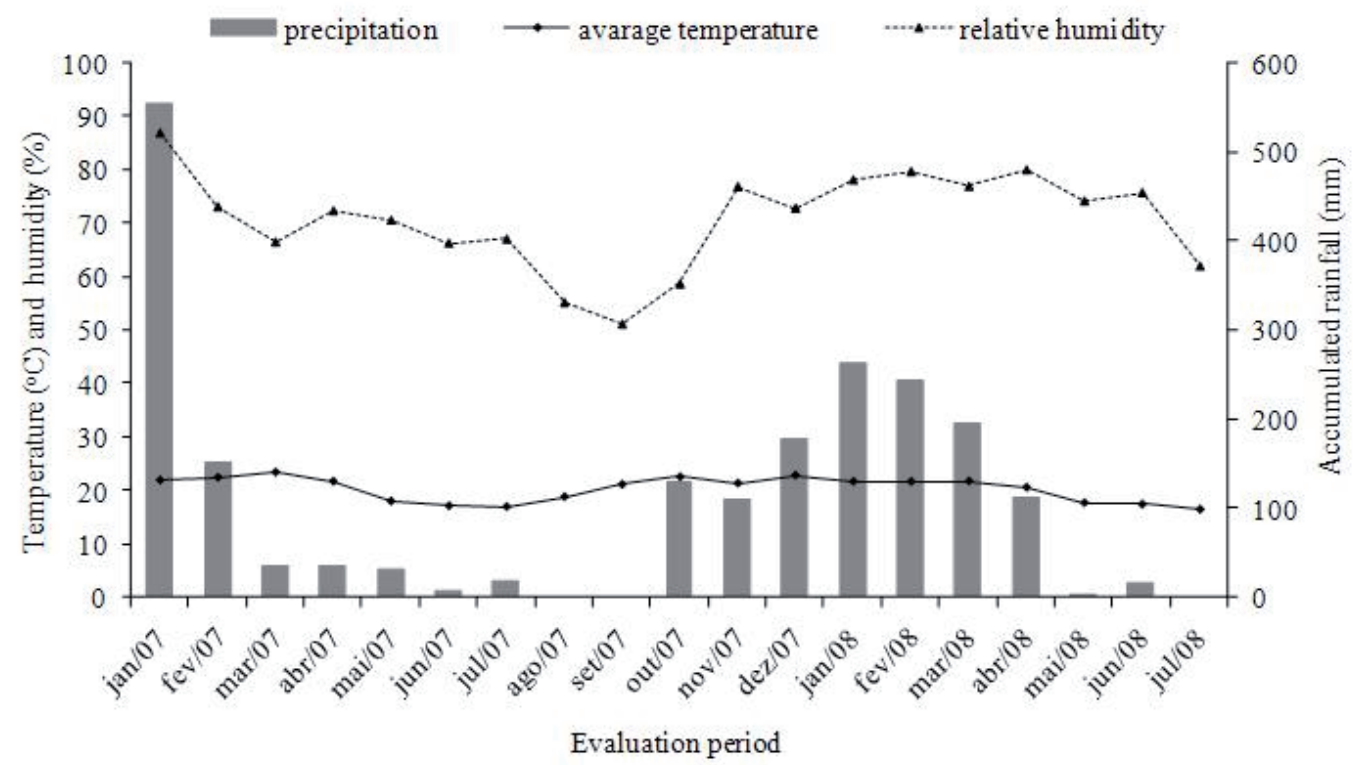

Source: Elaboration of the authors.

It was used ten-year-old 'Ponkan' mandarin trees (Citrus reticulata Blanco cv. Ponkan) grafted on 'Rangpur' lime (C. limonia Osbeck) and planted with spacing of $6 \mathrm{~m}$ between rows and $3 \mathrm{~m}$ between plants. The fertilization was performed according to soil and leaf analysis, splited in four applications and cultural treatments and pest control were performed according to technical recommendations for the culture.

In the first year, 2007, to promote the chemical thinning, plants were selected by productive potential, so that all plants subjected to treatment had a significant quantity of fruit. The treatments consisted of five Ethephon concentrations: 0, 150, 300, 450 and $600 \mathrm{mg} \mathrm{L}^{-1}$, applied at two fruit development stages: $30 \mathrm{~mm}$ and $40 \mathrm{~mm}$ of transverse diameter.

The experiment was set in a $5 \times 2$ factorial scheme, five Ethephon concentrations and two fruit development stages in randomized block with four replications. The experimental plots were composed of seven plants and the evaluations in the three plants of the center plot.

The plants were sprayed with commercial product ZAZ ${ }^{\circledR}$, soluble concentrate with $480 \mathrm{~g} \mathrm{~L}^{-1}$ 2-chloroethylphosphonic acid. The applications were carried in crown full extent (internal and external) to promote plant uniformity thinning after the period of fruit physiological drop in January 2007. 
In the second year, 2008, to observe the effect of chemical thinning for the previous year on occurrence of alternate bearing and productivity, the ethephon application was not realized.

At harvest, in June 2007 and 2008, it was determined the production per plant in boxes of $22 \mathrm{~kg}$ and yield per area, calculated as the plants number per area according to spacing. The yield production was determined considering fruit size characteristics, thus it was evaluated for the transverse and longitudinal diameters to verify if production was in accordance with the standard required by the destination market. These standards were considered in the fruit above 58 and $60 \mathrm{~mm}$ in diameter, longitudinal and transverse, respectively.

During 2008, plants were evaluated in relation to the fruit size produced and alternate bearing, which was calculated considering the plants number that showed total absence of fruit. To evaluate the size ten fruits were harvested per plant at the median part of the crown of each treatment to determine the mass $(\mathrm{g})$, transverse and longitudinal diameter $(\mathrm{mm})$ and the juice yield (\%) determined by relationship of juice volume extracted by juicer orange from ten fruits by its mass. From the variation of production evaluated in the two years the alternate bearing index was calculated using the formula $I=1 /(n-1)$ $\mathrm{x} \quad\{|(\mathrm{a} 2-\mathrm{a} 1)| /(\mathrm{a} 2+\mathrm{a} 1)+|(\mathrm{a}(\mathrm{n})-\mathrm{a}(\mathrm{n}-1))| /(\mathrm{a}(\mathrm{n})+\mathrm{a}(\mathrm{n}-1))\}$, where $\mathrm{n}=$ number of years, and $\mathrm{a} 1, \mathrm{a} 2, \ldots, \mathrm{a}(\mathrm{n}-1)$, $\mathrm{a}(\mathrm{n})=$ yield of the corresponding years (PEARCE; DOBERSEK-URBANC, 1967).

Data were submitted to variance analysis to evaluate differences between the factors and the polynomial regression to fit models, chosen on the basis of biological phenomenon and the significance of regression coefficients, $p \leq 0.05$.

\section{Results and Discussion}

There was not interaction between Ethephon concentrations applied and the fruit development stages for features evaluated. It was observed influence of different Ethephon concentrations $(p<0.05)$ on fruit yield in year that was done the thinning and in harvest of following year.

The estimated plant production showed linear growth with the increasing of Ethephon concentrations applied in the following year the thinning. In plants that were sprayed in 2007 with $600 \mathrm{mg} \mathrm{L}^{-1}$ concentration, the estimated production was 3.8 boxes of $22 \mathrm{~kg}$ per plant, representing an increase of $79.3 \%$ compared to plants that were not sprayed with Ethephon. In these plants the results from the 2008 harvest were higher than those observed in 2007, about 4.35 boxes of $22 \mathrm{~kg}$ per plant and increase of $128.3 \%$ in relation the plants that were not submitted to thinning (Figure 2a).

In plants sprayed with the highest Ethephon concentration, the estimated yield per hectare was 2,414 boxes of $22 \mathrm{~kg}$ in 2008 harvest an increase of 1,356 boxes compared to plants that were not subjected to thinning (Figure 2b). In 2007 harvest the yield was 2,107 boxes of $22 \mathrm{~kg} \mathrm{ha}^{-1}$ in plants that were sprayed with $600 \mathrm{mg} \mathrm{L}^{-1}$ concentration. The differences observed in yield of crop production in 2007 can be attributed to the small size of fruit in plants that were not subjected to thinning with those sprayed with the lowest Ethephon concentrations, hence the fruit majority was classified as noncommercial production.

This difference in the production yield shows that the thinning favored the alternate bearing reduction in the following year after its implementation. The low crop production in 2008, measured in plants that were not submitted to thinning and then sprayed with the Ethephon lowest concentration (150 mg $\mathrm{L}^{-1}$ ) in 2007 can be attributed the alternate bearing observed in some plants of these treatments, while all plants subjected to $300 \mathrm{mg} \mathrm{L}^{-1}$ concentrations thinning showed not alternate bearing (Figure 3). 
Figure 2. Yield per plant (a) and productivity (b) in 'Ponkan' mandarin tree submitted to chemical thinning in Perdões, southern Minas Gerais State, Brazil.
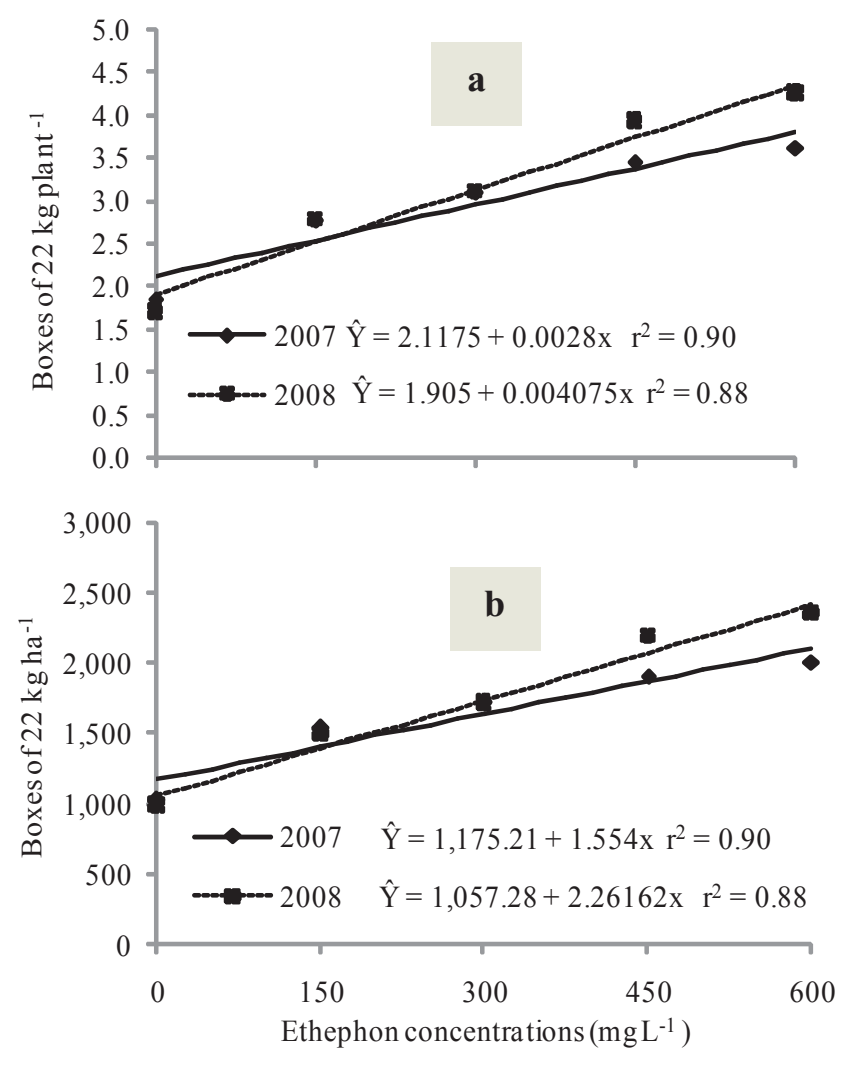

Source: Elaboration of the authors.

Figure 3. Alternate bearing (a) and alternate bearing index (b) evaluated at 'Ponkan' mandarin in 2008, following year to chemical thinning application in Perdões, southern Minas Gerais State, Brazil.
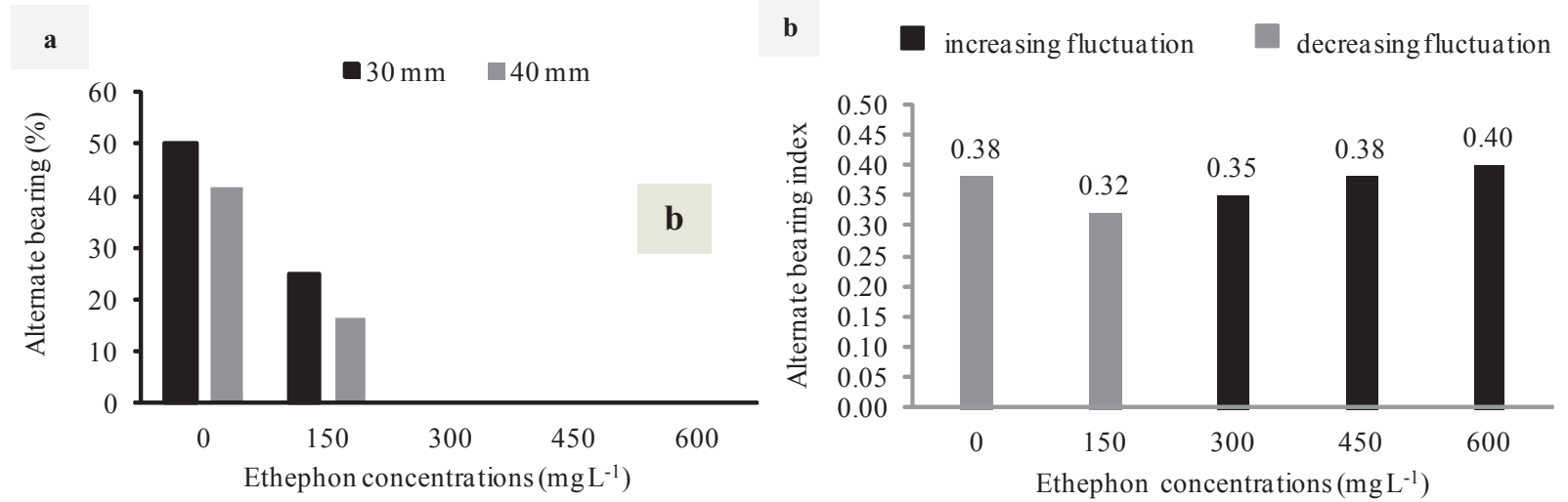

Source: Elaboration of the authors. 
Similar results were observed by Souza et al. (1993) in 'Montenegrina' mandarin decreasing the alternate bearing in a satisfactory manner with Ethephon application. Considering the linear behavior in relation to increased production, it can be justified by Ethephon concentrations which were used to promote the thinning, noting that some plants that were sprayed with concentration of 150 $\mathrm{mg} \mathrm{L}^{-1}$ did not produce in year of 2008 , compared to plants of other treatments which showed no alternate bearing (Figure 3a). This can be noticed by alternate bearing index that ranged from 0.32 to 0.40 (Figure $3 b)$ that according with the formula proposed by Pearce e Dobersek-Urbanc (1967) can vary between 0 and 1 ; the closer to zero the values, the smaller the yield fluctuation. However, variation indices of plants sprayed with a concentration of $150 \mathrm{mg} \mathrm{L}^{-1}$ Ethephon and without thinning showed decreasing variation relative to previous year and the plants of other concentrations the variation signified an increase in yield due to chemical thinning.

The high production observed in 2008 in plants subjected to $600 \mathrm{mg} \mathrm{L}^{-1}$ concentration chemical thinning shows that the fruit amount in plants influences the production of following year because of carbohydrate amount that is used (GOLDSCHMIDT, 1999), exerting a regulatory effect on yield production. This result suggests that thinning is a practice that should be done in 'Ponkan' mandarin tree every year, because, generally, plants that produce small amount of fruits have excessive production in following year.

With respect to fruit mass was observed quadratic behavior with the highest value of $218.2 \mathrm{~g}$ estimated with the Ethephon concentration of $316.6 \mathrm{mg} \mathrm{L}^{-1}$, which represented an increase of $11.49 \%$, compared to fruit mass evaluated in control treatment plants (Figure 4a).

Figure 4. Mass (a) and yield juice (b) measured in fruits of 'Ponkan' mandarin in 2008, following year to chemical thinning application in Perdões, southern Minas Gerais State, Brazil.
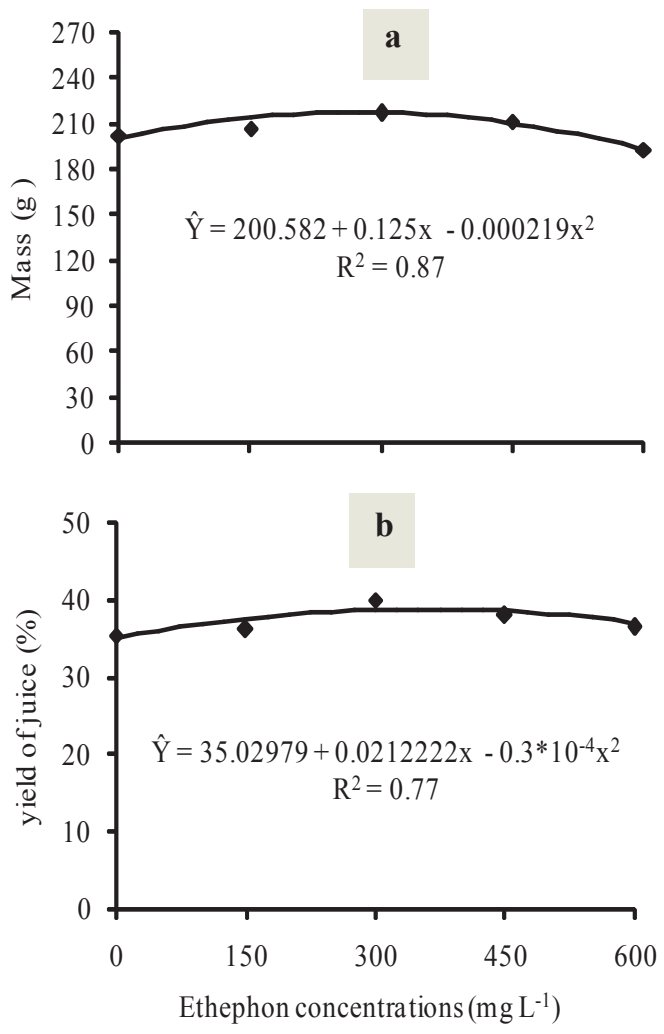

Source: Elaboration of the authors. 
The behavior observed on the mass of mandarins can be attributed to high production in plants that were subjected to thinning with Ethephon concentration of $600 \mathrm{mg} \mathrm{L}^{-1}$. In these plants the high fruits number per plant probably limited the fruit development, which is dependent of the supply assimilates (GARCÍA-LUIS et al., 2002). These results showed the strong relationship between source-sink which the excessive fruit number per plant influence in its size (GUARDIOLA; GARCÍA-LUIZ, 2000).

Similar behavior was observed in the juice yield (Figure 4b) with the largest percentage of 38.8\% estimated with the Ethephon concentration of $353.7 \mathrm{mg} \mathrm{L}^{-1}$, that represented increase of $11.23 \%$ compared to plants that were not subjected to thinning. The high juice yield was due the high mass observed in these fruits. Moreover, during the fruit growth and ripening period, there was sufficient water availability (Figure 1), that may have favored the filling of juice vesicles.

Regarding to transverse and longitudinal diameters evaluated in mandarins after chemical thinning (Figure 5) were not observed significant differences between different Ethephon concentrations applied to promote thinning in the following year after the application. Different behavior was observed in 2007, an increase in fruits diameter in plants sprayed with higher concentrations of Ethephon.

Figure 5. Diameter transverse and longitudinal measured in fruits of 'Ponkan' mandarin tree submitted to chemical thinning in Perdões, southern Minas Gerais State, Brazil.

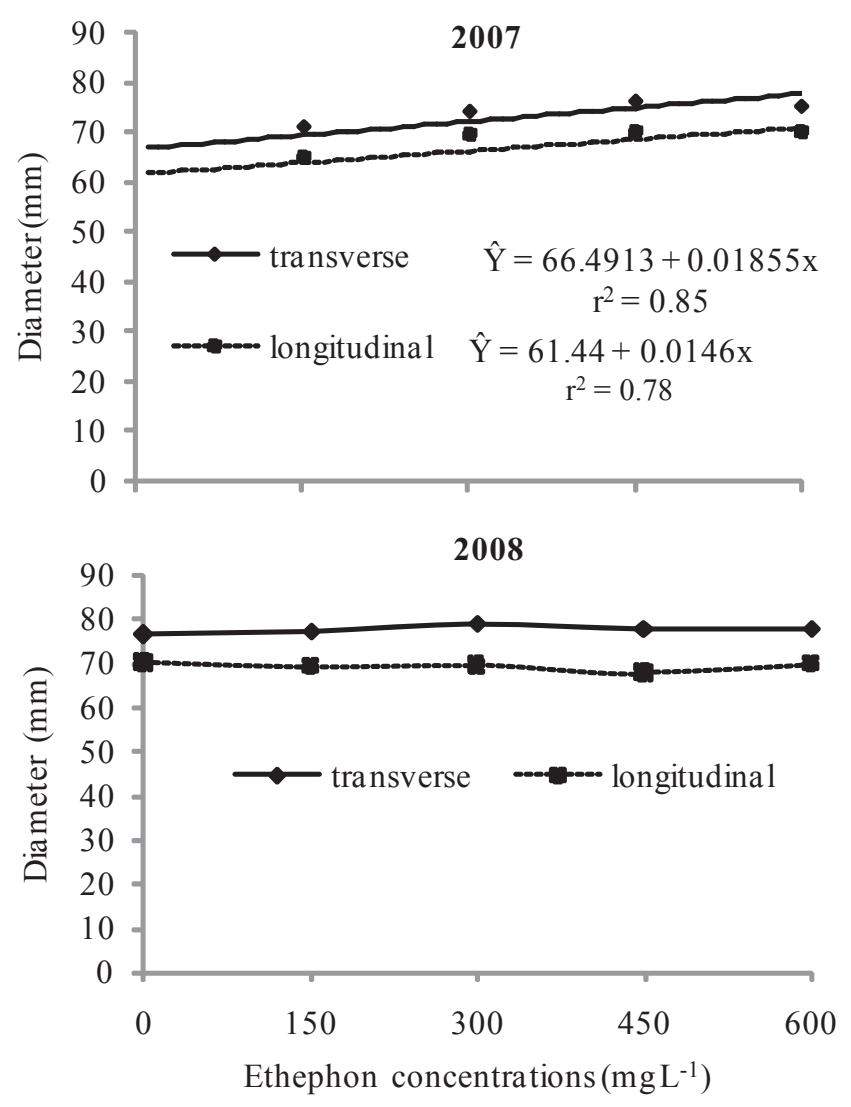

Source: Elaboration of the authors. 
This result may have occurred due the thinning has not been promoted in the second year of evaluation, so that all plants that produced maintained its fruits natural quantity that had lower availability of assimilates. This is because, the fruit growth is supported by several evidences including the increase of source-sink as a result of fruit thinning (IGLESIAs et al., 2003) and to change the characteristics related to fruit size is necessary to reduce the fruit number per plant (CRUZ et al., 2010). For this, during the initial stage of fruit development is necessary to apply growth regulators which ethylene operates instead as the hormonal activator to promote thinning (IGLESIAS et al., 2007).

Another aspect observed in plants submitted to thinning with the application of $600 \mathrm{mg} \mathrm{L}^{-1}$ of Ethephon in 2007, is that the yield per plant was high in 2008, possibly in function of greater amount of assimilates available due to the smaller number of fruits in the previous year. This behavior shows that the following year these plants may exhibit alternate bearing. And to avoid the problem chemical thinning should be a practice adopted by the producers of tangerines, order to maintain appropriate reserves to regulate the production over the years, maintaining a profitable activity.

Results of fruit size and production in following year of the Ethephon application suggest that the thinning practice should be performed every year in 'Ponkan' mandarin for improvement in their quality. However, for the thinning be effective on quality fruit is necessary Ethephon concentrations appropriate use, according to fruit development stage at the time of thinning, of climatic conditions and thinning intensity on fruit and leaf abscission that can affect the quality and yield.

\section{Conclusions}

The chemical thinning with the application of Ethephon at concentrations between $300 \mathrm{mg} \mathrm{L}^{-1}$ to $600 \mathrm{mg} \mathrm{L}^{-1}$ promotes yield regularity in 'Ponkan' mandarin trees.
Plants sprayed with $600 \mathrm{mg} \mathrm{L}^{-1}$ of Ethephon produced higher amounts of fruit in the following year to thinning.

\section{References}

CRUZ, M. C. M.; MOREIRA, R. A.; ARAUJO, N. A. Rentabilidade da tangerineira Ponkan submetida ao raleio químico comparada com o manejo convencional. Revista Brasileira de Fruticultura, Jaboticabal, v. 33, p. 447-454, 2011. Especial.

CRUZ, M. C. M.; RAMOS, J. D.; OLIVEIRA, D. L.; MARQUES, V. B.; VILLAR, L. Características físicoquímicas da tangerina 'Ponkan' submetida ao raleio químico em relação à disposição na copa. Ciência e Agrotecnologia, Lavras, v. 34, n. 1, p. 37-42, 2010.

GARCÍA-LUIS, A.; OLIVEIRA, M. E. M.; BORDÓN, Y.; SIQUEIRA, D. L.; TOMINAGA, S.; GUARDIOLA, J. L. Dry matter accumulation in citrus fruit is not limited by transport capacity of the pedicel. Annals of Botany, London, v. 90, n. 6, p. 755-764, 2002.

GOLDSCHMIDT, E. E. Carbohydrate supply as a critical factor for citrus fruit development and productivity. HortScience, Alexandria, v. 34, n. 6, p. 1020-1024, 1999.

GUARDIOLA, J. L.; GARCÍA-LUIZ, A. Increasing fruit size in citrus. Thining and stimulation of fruit growth. Plant Growth Regulation, Dordrecht, v. 31, n. 1-2, p. 121-132, 2000.

IGLESIAS, D. J.; CERCÓS, M.; COLMENEROFLORES, J. M.; NARANJO, M. A.; RÍOS, G.; CARRERA, E.; RUIZ-RIVERO, O.; LLISO, I.; MORILLON, R.; TADEO, F. R.; TALON, M. Physiology of citrus fruiting. Brazilian Journal of Plant Physiology, Campos dos Goytacazes, v. 19, n. 4, p. 333-362, 2007.

IGLESIAS, D. J.; TADEO, F. R.; PRIMO-MILLO, E.; TALÓN, M. Fruit set dependence on carbohydrate availability in citrus trees. Tree Physiology, Victoria, v. 23, n. 3, p. 199-204, 2003.

LEITE, G. H. P.; CRUSCIOL, C. A. C.; SILVA, M. A. Desenvolvimento e produtividade da cana-de-açúcar após aplicação de reguladores vegetais em meio de safra. Semina: Ciências Agrárias, Londrina, v. 32, n. 1, p. 129138, 2011.

PEARCE, S. C.; DOBERSEK-URBANC, S. The measurements of irregularity in growth and cropping. Journal of Horticultural Science, Ashford, v. 42, p. 295305, 1967. 
SARTORI, I. A.; KOLLER, O. C.; THEISEN, S.; SOUZA, P. V. D.; BENDER, R. J.; MARODIN, G. A. B. Efeito da poda, raleio de frutos e uso de fitorreguladores na produção de tangerinas (Citrus deliciosa Tenore) cv. Montenegrina. Revista Brasileira de Fruticultura, Jaboticabal, v. 29, n. 1, p. 5-10, 2007.

SCHWARZ, S. F.; KOLLER, O. C.; NIENOW, A. A. Intensidades e épocas de raleio manual em Tangerineira
'Montenegrina'. Pesquisa Agropecuária Brasileira, Brasília, v. 27, n. 8, p. 1161-1165, 1992.

SOUZA, P. V. D.; KOLlER, O. C.; SCHWARZ, S. F.; BARRADAS, C. I. N. Influência de concentrações de etefon e pressões de pulverização foliar sobre a produção de frutos e o teor de substâncias de reserva em tangerineiras. Pesquisa Agropecuária Brasileira, Brasília, v. 28, n. 5, p. 613-619, 1993. 
